\title{
Three Theses on the Current Crisis of International Liberalism
}

\author{
DAVID SINGH GREWAL*
}

\begin{abstract}
This essay advances three theses on the current crisis of international liberalism. First, it is a composite one, comprising interrelated crises of domestic political representation and of global governance affecting the international and supranational arrangements that were constructed in the post-war period. Second, the crisis is a specific development of neoliberal governance, which requires distinguishing international liberalism's two historical variants: "embedded liberalism" and "neoliberalism." The turn from the post-war regime of "embedded liberalism" to the "neoliberalism" of recent decades has had the effect of undoing the domestic social contracts that underlay post-war political stability even while failing to secure peace and prosperity internationally. Third, neoliberal governance operates through a distinct form of legality from the embedded liberalism of the post-war period. The turn to neoliberalism involves a shift from the inter-state orientation that characterized the first decades of international liberalism to a "dialectic of globalization," in which newly empowered transnational activity across states generates pressure for supranational governance above them. This dialectic has the effect of undermining the international legal order on which liberalism has depended historically, which suggests that

* Professor, Yale Law School. This essay began as a presentation at a March 2017 conference hosted by the Indiana Journal of Global Legal Studies. I am grateful to its organizers, particularly Fred Aman, and to my fellow panelists, particularly Saskia Sassen, for their comments and inspiration. I am also grateful to Alessandro Aresu, Daniela Cammack, Georgios Dimitropoulos, Stefan Eich, Jack Goldsmith, Jennifer Harris, Robert Hockett, Amy Kapczynski, Madhav Khosla, Jan Komárek, Itamar Mann, Samuel Moyn, Jedediah Purdy, Sanjay Reddy, Ganesh Sitaraman, Richard Tuck, and the students in the Law \& Political Economy seminar at Yale Law School for discussion, criticism, and inspiration. Srinath Reddy provided superb research assistance and the editors of the Indiana Journal of Global Legal Studies were insightful and generous throughout the publication process.
\end{abstract}

Indiana Journal of Global Legal Studies Vol. 25 \#2 (Summer 2018)

(C) Indiana University Maurer School of Law 
the present crisis is at root the product of an internal transformation rather than the result of competition with external enemies.

\section{INTRODUCTION: THE CRISIS OF INTERNATIONAL LIBERALISM}

By the beginning of 2017, commentators of many stripes seemed to agree that something called "international liberalism" was in trouble. From the far-right to the far-left of the political spectrum, the "post-war international liberal order" (or some variant on that theme) was portrayed as endangered, if not already at an end, with a series of political upsets given as evidence. Harvard's Joseph Nye questioned in the pages of Foreign Affairs "will the liberal order survive?"1 while his "realist" colleague Stephen Walt, diagnosed "the collapse of the liberal world order" in Foreign Policy. ${ }^{2}$ Michael Anton, a conservative intellectual who now works in the Trump administration, argued that many aspects of the "liberal international order" were no longer in America's national interest. ${ }^{3}$ Some leftist intellectuals, such as the Nation's foreign affairs columnist Patrick Lawrence, celebrated the end of the "liberal, postwar order" and its oppressions, ${ }^{4}$ while Samuel Moyn argued in Dissent that "liberal internationalism" had failed both liberalism and internationalism through its support for endless American wars. $^{5}$ Contributors to Jacobin debated whether the "American empire" was really in decline at all, ${ }^{6}$ or had merely entered a "decadent" phase in the context of globalized neoliberalism. ${ }^{7}$

Meanwhile, the pages of the establishment North Atlantic papers such as The New York Times, Washington Post, Le Monde Diplomatique, $S Z, F A Z$, and others filled with crisis talk about the end of liberalism,

1. See Joseph Nye, Will the Liberal Order Survive?, FoREIGN AFF., Jan.-Feb. 2017, https://www.foreignaffairs.com/articles/2016-12-12/will-liberal-order-survive.

2. Stephen Walt, The Collapse of the Liberal World Order, ForEIGN POLICY (June 26, 2016, 4:43 PM), http://foreignpolicy.com/2016/06/26/the-collapse-of-the-liberal-world-ordereuropean-union-brexit-donald-trump/.

3. See generally Michael Anton, America and the Liberal International Order, 1 AM. AFF. 113 (2017) (arguing that many aspects of the "liberal international order" were no longer in America's national interest).

4. See Patrick Lawrence, The Liberal, Postwar 'Order' is Dying-and That's a Good Thing, NATION (Jan. 25, 2017), https:/www.thenation.com/article/the-liberal-postwarorder-is-dying-and-thats-a-good-thing/.

5. See Samuel Moyn, Beyond Liberal Internationalism, Dissent, Winter 2017, 10814.

6. See generally Edward Hunt, The American Empire Isn't in Decline, JACOBIN (Mar. 13, 2017), https://www.jacobinmag.com/2017/03/obama-trump-mattis-united-states-empire (arguing that the American empire "is here to stay").

7. Doug Henwood, The Decline of the American Empire, JACOBIN (Sept. 27, 2013), https://jacobinmag.com/2013/09/the-decline-of-the-american-empire/. 
while the "end of globalization" became a major theme in the business dailies and weeklies. Never far behind, think tanks and pressure groups took up the theme in longer analyses. To consider just two, the "Davos" group of international business and policy elites, formally the "World Economic Forum," issued a white paper on "strengthening the liberal world order," 8 while former British Prime Minister Tony Blair launched an eponymous "Institute for Global Change," with a focus on fighting "populism" and "renewing the [political] centre."9 It would be difficult for any reader-particularly of this journal, given its mission to analyze globalization ${ }^{10}$ - to have missed this major theme in the commentary of the moment.

In this essay, I will argue that "international liberalism" is indeed in trouble, but for reasons that have not been adequately examined, and which have to do with changes in the nature of globalization itself. The essay proceeds as a series of three interconnected but distinct theses concerning the crisis of international liberalism. First, I argue that the crisis of international liberalism should be understood as a composite crisis of domestic political representation and a related crisis of "global governance" affecting the international and supranational arrangements that were constructed in the post-war period. Second, I argue that the crisis of international liberalism should be understood as a specific crisis of neoliberal governance, which requires distinguishing liberalism's two historical variants: "embedded liberalism" and "neoliberalism." Finally, I argue that neoliberalism relies on a distinct form of legality from the embedded liberalism of the post-war period. Specifically, the neoliberal effort to use private market orderings as the basis for global governance generates what I call the "dialectic of globalization," a movement from transnationalism to supranationalism that undermines the inter-state legal order on which international liberalism has depended.

\section{THE COMPOSITE CRISIS OF INTERNATIONAL LIBERALISM}

The first thesis is that the crisis of international liberalism must be understood as a composite crisis. At the domestic level, a "crisis of representation" has hollowed out support for the establishment parties

8. See Strengthening the Liberal World Order, GLOB. AGENDA CoUnCIL ON THE U.S. (2016), http://www3.weforum.org/docs/WEF_US_GAC_Strengthening_Liberal_World_Ord er_White_Paper_US.pdf.

9. See Tony Blair, Renewing the Centre, Tony Blair Inst. For Glob. Change, (Mar. 17, 2017), https://institute.global/insight/renewing-centre/renewing-centre.

10. See Our Mission, IND. J. GLOB. LEG. STUD., http://ijgls.indiana.edu/about/ourmission/. 
that flourished during the post-war era. Reciprocally, at the global level, we see a crisis of legitimation concerning the international and supranational legal constructions that these establishment parties built, and on the success of which they now partly depend.

In developing this argument, it is worth beginning with the role of the United States in the global order. The institutions and practices central to the liberalism of the post-war period resulted, in large part, from American efforts to bolster European and Asian allies through military and economic means. This post-war liberalism received a new boost and, as I argue below, a new inflection after the end of the Cold War, when American leadership in political, economic, and military matters went unchallenged for about a decade. International liberalism has thus depended on and, in significant respects, still requires the domestic political support it could garner from both parties in the United States over many decades. ${ }^{11}$

The immediate prompt to much of the crisis talk about international liberalism was the unanticipated election of Donald Trump as president of the United States. His election reveals that the political alignments that have undergirded the American party system since at least the Reagan-era appear to be shifting. In both the Republican and Democratic parties, new divisions pit members of the party "base" against "elites," who are presumed to share more in common with each other and with other foreign elites than with the people whom they are supposed to represent. ${ }^{12}$ This dynamic did not go unnoticed and has generated some change, at least in the last contest for the White House. While President Trump squared himself against many tenets of international liberalism, it is worth remembering that all three leading candidates in the last American presidential election-Donald Trump, Hillary Clinton, and Bernie Sanders-rejected President Obama's proposed "Trans-Pacific Partnership."13 Skepticism about further

11. Along these lines, Ikenberry argues there is not a crisis of "liberal internationalism" but of the American-led post-war order, caused in part by its very success. See G. John Ikenberry, The Future of Liberal World Order, 16 JAPANESE J. PoL. SCI. 450, 451 (2015).

12. For a journalistic discussion of this dynamic in the Republican party, see Nicholas Confessore, How the G.O.P. Elite Lost its Voters to Donald Trump, N.Y. TIMEs (Mar. 28, 2016) https://www.nytimes.com/2016/03/28/us/politics/donald-trump-republican-voters.ht $\mathrm{ml}$; and in the Democratic Party, see Stanley Greenberg, The Democrats' 'Working-Class Problem,' AM. PRosPect (June 1, 2017) http://prospect.org/article/democrats'-workingclass-problem'.

13. President Trump formally withdrew the United States from the TPP. For an analysis of Clinton's stance, see David Singh Grewal, Why Hillary Clinton is Right on the TPP, HuFFPosT (Oct. 14, 2015), https://www.huffingtonpost.com/david-singh-grewal/whyhillary-clinton-is-ri_b_8295420.html; for Sanders' position, see Press Release, Senator Bernie Sanders, The Trans-Pacific Trade (TPP) Agreement Must Be Defeated (Dec. 29, 
economic globalization-and the role that the United States can afford to play in it-is thus no longer restricted to the political extremes in the United States. ${ }^{14}$ Nevertheless, both parties remain deeply divided internally over how to respond to it.

A shift in long-established domestic political constellations is even more advanced in Europe. The last year saw so-called "populist" rejections of British membership in the European Union ("Brexit") and of a reformist streamlining of the Italian constitution; ${ }^{15}$ the evident failure of liberal political culture to take hold in Hungary, Poland, and elsewhere in Eastern Europe; ${ }^{16}$ and an upending of established political patterns in even the core states of the European Union. While the project of deeper European unification may have been given a paradoxical boost by Brexit-which may allow fuller integration under the aegis of a renewed Franco-German alliance ${ }^{17}$-parties mobilized in explicit opposition to it are now arrayed across the continent. In Germany, France, Italy, Spain, Greece, and elsewhere, the center-right and center-left political parties that governed during the post-war era have lost power to new arrivals-or are in danger of doing so. ${ }^{18}$ In particular, far-right parties have seized the opportunity created by the unwillingness or inability of established center-left parties to resist Brussels's turn to austerity. ${ }^{19}$ The predictable-indeed, widely

2014), https://www.sanders.senate.gov/download/the-trans-pacific-trade-tpp-agreementmust-be-defeated?inline=file.

14. For an analysis of declining U.S. support for the international public goods that make up "globalization," see Michael Pettis, How Much Longer Can the Global Trading System Last?, CHINA FIN. MKTS. (Sept. 28, 2014), http://carnegieendowment.org /chinafinancialmarkets/56822.

15. See Regina Krieger, Italian Referendum: Populism's Next Battleground, HANDELSBLATT (Nov. 30, 2016), https://global.handelsblatt.com/politics/populisms-nextbattleground-653213.

16. See, e.g., R. Daniel Kelemen, Europe's Other Democratic Deficit: National Authoritarianism in Europe's Democratic Union, 52 Gov'T \& OPPOSITION 211 (2017) (describing the rejection of liberal democracy in the European Union).

17. See Stephen D. Collins, Europe's United Future After Brexit, 29 Global Change, PEACE \& SECURITY 311 (2017).

18. As the late Peter Mair, perhaps the foremost comparative scholar of political parties, put it in 2013: "The age of party democracy has passed. Although the parties themselves remain, they have become so disconnected from the wider society, and pursue a form of competition that is so lacking in meaning, that they no longer seem capable of sustaining democracy." He did not live to see the rise of new parties, whether of the far right or the "radical center" (such as Emmanuel Macron's En Marche!), which further confirm his diagnosis of the collapse of the age of party democracy. PETER MAIR, RULING THE VOID 1 (2013).

19. See Europe's Rising Far Right: A Guide to the Most Prominent Parties, N.Y. TIMES (Dec. 4, 2016), https://www.nytimes.com/interactive/2016/world/europe/europe-far-rightpolitical-parties-listy.html. 
predicted 20 -result is that the center-left parties have been hollowed out, falling on their swords to defend an unpopular form of European integration and offering their support to the established parties of the center-right in contests with new parties and fringe movements. Notwithstanding its reputation as a bastion of European stability, even Germany has recently experienced electoral turmoil and the rise of farright parties, with unclear consequences for its political future and for the European Union in which it has become primus inter pares. ${ }^{21}$

Similar dynamics elsewhere in the world contribute to a growing sense of unease if not outright unrest in a wide range of countries. ${ }^{22}$ Political scientists have identified declining confidence in democratic decision-making. Relatedly, the rise of an "authoritarian" style of politics has been diagnosed in the United States and elsewhere, from Turkey to India to China to Russia. ${ }^{23}$ Authoritarian politics is often given a major boost by the ongoing corruption scandals threatening or even bringing down governments. ${ }^{24}$

Far from being a specific regional problem, the events and trends surveyed above suggest a pervasive crisis of representation that afflicts countries at all levels of development and in all regions. The "crisis of representation" was first theorized by the Italian social theorist Antonio Gramsci as the condition in which established political parties lose an "organic" link to their constituencies. This generates, he argued, crises of authority, and introduces a tendency toward what he called

20. David Singh Grewal, The Laws of Capitalism, 128 HARV. L. REv. 626, 666 ("What, then, can we expect from today's unhappy alliance between the remnants of the old workers' parties of Western Europe and the Bundesbank?").

21. See Yascha Mounk, The End of Germany Stability, SLATE (Nov. 20, 2017, 11:39 AM), http://www.slate.com/articles/news_and_politics/the_good_fight/2017/11/germany_s_c oalition_talks_collapse_threatening_stability.html.

22. See Roberto Stefan Foa \& Yascha Mounk, The Democratic Disconnect, 27 J. DEMOCRACY 5, 16 (2016).

23. See generally BASharat Peer, A Question of Order: India, Turkey, And the RETURN OF STRONGMEN (2017) (emphasizing the importance in understanding the failings of democracies like India and Turkey if liberal traditions are to be protected and nourished). On the recent Chinese turn toward one-person rule under Xi Jinping, see Richard McGregor et al., Xi Won't Go, CHINAFILE (Feb. 25, 2018), http://www. chinafile.com/conversation/xi-wont-go.

24. See Ashutosh Varshney, India's Democracy at 70: Growth, Inequality, and Nationalism, 28 J. Democracy 41 (2017); Jonathan Bernstein, Chile's Democracy Enters a Rough Patch, Bloomberg View (Nov. 18, 2017, 8:00 AM), https://www.bloomberg.com /view/articles/2017-11-18/chile-s-democracy-enters-a-rough-patch; Chayenne Polimedio, Brazilians Are Losing Faith in Democracy and Considering a Return to Military Rule, Vox (Sept. 19, 2017, 1:00 PM), https://www.vox.com/polyarchy/2017/9/19/16333360/brazilianslosing-faith-democracy. 
"Caesarism."25 A turn toward Caesarist politics is visible today not only in the increase in authoritarian political styles, but also the rise of discretionary "executive power," often rationalized on emergency grounds, even in established liberal democracies. ${ }^{26}$

In conjunction with the crisis of domestic political representation, the international institutions that anchored the Western world following the Second World War-and which were significantly globalized with the end of the Cold War-are now being questioned or attacked from many points on the political spectrum. With these institutions experiencing wavering support in Europe and the United States, it remains unclear how rising powers, particularly China, will work with them. ${ }^{27}$ Institutions subject to criticism include not only the North Atlantic Treaty Organization (NATO), but the World Trade Organization (WTO), the European Union (EU), the North American Free Trade Agreement (NAFTA), and other trade agreements undergirding "globalization." And while opposition to international economic integration under the aegis of the EU or the WTO has long been a feature of political discourse on both left and right, ${ }^{28}$ the controversy over the future of NATO is relatively new-and far from being a minor phenomenon, it has been given a recent boost by the

25. See Antonio Gramsci, Selections from the Prison Notebooks 445 (Quentin Hoare \& Geoffrey Nowell Smith eds., 1999).

26. For a discussion of democratic responses that avoid the top-down, executive-driven response to emergencies characteristic of the past decade, see generally BONNIE HoNIG, EMERgEnCy Politics: PARAdox, LAW, DEMOCRACy (2009). For a critical account of the rise of executive power and the "imperial presidency," see generally BRUCE ACKERMAN, The DeCline AND FALl of THE AMERICAN REPUBLIC (2013).

27. On China as a supporter of the global order, see Thomas E. Kellogg, Xi's Davos Speech: Is China the New Champion for the Liberal International Order?, THE DIPLOMAT (Jan. 24, 2017), https://thediplomat.com/2017/01/xis-davos-speech-is-china-the-new-champ ion-for-the-liberal-international-order/. On its bid for soft power, see The Subtleties of Soft Power: China is Spending Billions to Make the World Love It, ECONOMIST (Mar. 23, 2017), https://www.economist.com/news/china/21719508-can-money-buy-sort-thing-china-

spending-billions-make-world-love-it. And for a discussion of its alleged "manipulation" of Western decision-makers, see Sunlight v Subversion: What to Do About China's "Sharp Power,” Economist (Dec. 14, 2017), https://www.economist.com/news/leaders/21732524china-manipulating-decision-makers-western-democracies-best-defence. The move to position China (along with Germany) as the new bulwark of liberal globalization following the American election of Trump has come into conflict with its apparent transformation from a state under one-party rule to a state under one-person rule. See Steven Erlanger, Europe Once Saw Xi Jinping as a Hedge Against Trump. Not Anymore., N.Y. TIMES, Mar. 5, 2018, at A9.

28. See Dani Rodrik, Populism and the Economics of Globalization (Nat'l Bureau of Econ. Research, Working Paper No. 23559, 2017). 
American president. ${ }^{29}$ Likewise, even international courts of relatively little consequence have become an outsized target of domestic political hostility in unexpected countries. ${ }^{30}$

At a foundational level, it is the pervasive crisis of domestic political representation that most threatens international liberalism, which depends on the ongoing support of constituencies in the core liberal states. The crisis of international liberalism should thus be understood as a composite crisis consisting of a domestic crisis of political representation and a related crisis of legitimacy affecting the international and supranational constructions of the post-war era. The crisis of representation and the crisis of what we might call "global governance" are connected because political representation and the institutions of global governance gain their legitimacy from similar sources-mainly, popular sovereignty and "outcome legitimacy." Globalization has put both these sources of legitimation under pressure. The crisis of international liberalism may seem to have appeared suddenly with the unexpected election of Donald Trump or the unexpected decision of the British people to leave the European Union, but the deeper trend has been the slow erosion of its legitimacy over the last decade or longer.

The main source of political legitimacy in modernity comes from popular sovereignty, which remains the foundational principle of our age, however unrealized it tends to be in practice. ${ }^{31}$ The relationship between political representation and popular sovereignty is far too vast a subject to canvass in this essay, but it is worth noting that representation is legitimated by its responsiveness to mass political mobilization (unlike, in earlier eras, where representation was expressly opposed to direct democratic decision-making). ${ }^{32}$ However, military alliances, international economic deals, or decisions of international courts are seldom the products of mass political mobilization. Instead, they tend to be the constructions of governmental elites. Their

29. For Trump's criticism of NATO, see Michael R. Gordon \& Niraj Chokshi, Trump Criticizes NATO and Hopes for 'Good Deals' with Russia, N.Y. TIMES (Jan. 15, 2017), https://www.nytimes.com/2017/01/15/world/europe/donald-trump-nato.html.

30. For example, the South African government's attempted withdrawal from the International Criminal Court, which was subsequently declared "invalid" by its constitutional court, see South Africa's Decision to Leave ICC Ruled 'Invalid', BBC NEwS (Feb. 22, 2017), http://www.bbc.com/news/world-africa-39050408.

31. See David Singh Grewal \& Jedediah Purdy, The Original Theory of Constitutionalism, 127 YALE L.J. 664, 668 (2018).

32. See Bernard Manin, The Principles of Representative Government 1 (John Dunn et al. eds., 1997) ("Contemporary democratic governments have evolved from a political system that was conceived by its founders as opposed to democracy.”). 
legitimacy thus depends more on the outcomes they deliver than any direct connection to popular will.

This second, and less foundational source of legitimation is sometimes called "outcome" or "output legitimacy." 33 It turns on the achievement of favorable outcomes by political elites, which helps to justify or compensate for the sequestering of ongoing decision-making power away from ordinary citizens. A focus on such consequentialist justifications of policy-making is particularly pronounced in the European Union, for the obvious reason of its "democratic deficit," but beneficial outcomes serve to legitimate a wide array of other international institutions as well. ${ }^{34}$

Viewed in terms of outcome legitimacy, the conditions of the postwar world were generally favorable to the political regimes of the North Atlantic, united under broad American leadership and grounded in stable party coalitions in the core liberal democracies. This stability bolstered the growth of international and supranational institutions. The institutions of international liberalism promised peace and prosperity and arguably delivered them for many decades, which reinforced the post-war domestic political coalitions that underwrote them. The favorable conditions included, prominently, a historically unprecedented combination of high and widely shared growth ${ }^{35}$ and a set of shared geopolitical imperatives foisted on otherwise divergent national interests by the great-power rivalry of the Cold War. ${ }^{36}$

33. See Fritz Scharpf, Governing In Europe 6 (1998); see also Fritz W. Scharpf, Economic Integration, Democracy and the Welfare State, 4 J. EUR. PUB. PoL'Y 18, 19 (1997). See generally Fritz W. Scharpf, Games ReAl ACtors Play: ACTOR-Centered InstitutionAlism IN POLICY RESEARCH 153-55 (1997) (discussing “output legitimacy" in the context of economic integration). Relatedly, the treaties underlying the EU's supranational constitutional order may be assessed in a "functionalist" frame. See TURKuler ISIKSEL, EuRope's Functional CONSTITUTION: A TheORY OF Constitutionalism Beyond the State 57-94 (2016). For a related discussion of a "messianic" legitimacy in the EU, see J. H. H. Weiler, In the Face of Crisis: Input Legitimacy, Output Legitimacy and the Political Messianism of European Integration, 34 J. EUR. INTEGRATION 825 (2012).

34. On the European Union's "democratic deficit," see Richard Bellamy \& Dario Castiglione, Reflections on the European Democratic Deficit, in DEMOCRACY IN THE EUROPEAN UNION: INTEGRATION THROUGH DELIBERATION 65, 69 (2000) ("There is little doubt that the structure of European Governance does not fully conform to any meaningful interpretation of the many standard definitions of democracy.").

35. See Thomas Piketty, CAPital in the Twenty-Finst Century 96-99 (2014); David Singh Grewal, The Laws of Capitalism, 128 HARV. L. REV. 626 (2014); David Singh Grewal \& Jedediah Purdy, Inequality Rediscovered, 18 THEORETICAL INQUIRIES IN L. 61 (2017).

36. See Robert D. BlackWell \& Jennifer M. HARris, War By Other Means: GEOECONOMICS AND STATECRAFT 177-78 (2016). 
However, with the end of the post-war trente glorieuses ${ }^{37}$-and especially, following the end of the Cold War-increasing "globalization" has altered the balance of forces both within and beyond countries in ways that call the legitimacy of international liberalism into question.

Economic globalization has tended to undermine popular sovereignty by making it more difficult to use the traditional instruments of national politics to manage transnational flows of capital, information, goods, and people. ${ }^{38}$ Relatedly, it has made national politics more susceptible to elite capture in conjunction with these trends. Thus, even as more is asked of the state, it appears ever able to do less. It has not helped the case for globalization that many of the regulatory powers of the state seem either to be diminished in the context of increased cross-border activity or transferred to supranational agencies that usually lack clear mandates from domestic political majorities, as I discuss further below. Either way, popular sovereignty seems threatened (de facto or de jure) by globalization-and international organizations have predictably come under attack.

Moreover, the last decade of globalization has failed to generate the beneficial outcomes that domestic constituencies had come to take for granted-and which could partly compensate for the sequestering of decision-making power away from them. The promise of peace has been undermined by increasing international rivalries and conflicts, including a renewal of the historic enmities between Russia and China and "the West," and the tragic collapse of the Middle East into an abyss of war and military dictatorships after the failed hopes of the so-called Arab Spring. ${ }^{39}$ Meanwhile, the failure of broad-based economic recovery from the financial crisis in 2007 and 2008 that hit the rich world means that roughly a quarter to a half of the young people in many European countries are now unemployed or underemployed-and have been for

37. The three decades of the post-war period, from roughly $1945-1975$, were termed in France (and elsewhere), the trente glorieuses ("thirty glorious years") for their combination of high and widely shared growth. See David Singh Grewal, Closing Remarks: Law and Inequality After the Crisis, 35 YALE L. \& POL'Y REV. 337, 338-39 (2016) (listing the terms by which the post-war economic boom was known in various countries).

38. See Susan Strange, The Erosion of the State, 96 CuRREnT Hist. 365 (1997); see also DANi RodriK, HAS GLOBALIZATION GONE TOO FAR? 36 (1997). On America's increasingly oligarchic politics, see Martin Gilens \& Benjamin I. Page, Testing Theories of American Politics: Elites, Interest Groups, and Average Citizens, 12 PERSP. ON PoL. 564, 566 (2014). For a study of elite capture of policymaking in international trade law, see Cory Adkins \& David Singh Grewal, Two Views of International Trade in the Constitutional Order, 94 TEX. L. REV. 1495 (2016).

39. See Noah Feldman, The Fall of the Arab Spring, YAle L. SCH. OCCASIONAL PAPERS No. 9 (2013), http://digitalcommons.law.yale.edu/cgi/viewcontent.cgi?article=1010\&con text=ylsop_papers. 
almost a decade. ${ }^{40}$ This fact suggests that the post-war prosperity that underwrote domestic social compacts will be unavailable for future generations. In the United States, dramatic statistics show the basic collapse of economic security for working class people: over a third of manufacturing jobs have disappeared since the year 2000, ${ }^{41}$ while the bottom 50 percent of the income distribution has experienced a slight decline in pre-tax income since the mid-1970s (by contrast with the dramatic growth of other percentiles, especially at the very top). ${ }^{42}$ The political effects of these significant economic changes on U.S. domestic politics-and the American-led international order, particularly with respect to global economic integration-are perhaps only now being felt in earnest.

Put differently, it may be argued that the fate of the political parties that led the post-war world, and the international institutions they helped put in place, are linked through feedback loops that generate either virtuous or vicious cycles. Trusted domestic representatives provide legitimation for international or supranational institutions, whose success at delivering outcomes becomes self-justifying and reinforces the political coalitions that supported them. This is the virtuous circle. But if the international constructions fail to deliver on favorable outcomes, they will tend to undermine the party leaders (or party-platforms) that supported them, and give credence to criticisms voiced by new parties and entrepreneurial newcomers in electoral contests-which may, in turn, undermine the capacity of international institutions to deliver outcomes by depriving them of needed domestic political support. But the reason why beneficial outcomes can be achieved in any period requires a deeper examination of changes in international liberalism itself.

40. See European Commission, Youth Unemployment, EUROSTAT (Nov. 30, 2017), http://ec.europa.eu/eurostat/statistics-explained/index.php/Youth_unemployment.

41. On manufacturing losses, see Robert E. Scott, Manufacturing Job Loss: Trade, Not Productivity, is the Culprit, ECON. POL'Y InST. BRIEF No. 402 (Aug. 11, 2015), http://www.epi.org/publications/manufacturing-job-loss-trade-not-productivity-is-theculprit/. On data concerning the bottom fifty percent, see Emmanuel Saez \& GabrielZucman, Economic Growth in the United States: A Tale of Two Countries, WASH. CTR. FOR EQUITABLE GROWTH (Sept. 6, 2016), http://equitablegrowth.org/researchanalysis/economic-growth-in-the-united-states-a-tale-of-two-countries/.

42. See Thomas Piketty, Emmanuel Saez, \& Gabriel Zucman, Distributional National Accounts: Methods and Estimates for the United States 8 (Wash. Ctr. for Equitable Growth, Working Paper No. 12, 2016). For an overview of the findings, see Jeremy Ashkenas, Nine New Findings About Income Inequality in the United States, N.Y. TIMES (Dec. 12, 2016). 


\section{EMBEDDED LIBERALISM AND NEOLIBERALISM}

The second thesis is that the crisis of international liberalism, which can be broken into related crises of domestic representation and of global governance, should be understood as a specific crisis of neoliberalism. Arguing so requires distinguishing liberalism's two historical variants: "embedded liberalism" and "neoliberalism." Unfortunately, much of the commentary on the alleged crisis of "international liberalism" fails to distinguish critically between its present neoliberal orientation and its post-war instantiation. Anxious commentators and political establishments the world over are understandably keen to claim the broad mantle of "international liberalism," with its implicit or explicit threat that only the present status quo keeps us from the abyss of war and depression. But in so doing, they threaten the viability of what was genuinely worth defending in the liberal settlements of the last century, and they unwittingly conspire with liberalism's enemies in its gradual unraveling. ${ }^{43}$

As discussed above, the international liberalism of the post-war world began as an alliance of states that understood themselves as liberal, some of them longstanding exemplars of liberal political culture (e.g., the United Kingdom, the Netherlands); others recently defeated fascist regimes now pressed into the cause (e.g., Germany, Japan). ${ }^{44}$ They were aligned against the Soviet Union, and, in a less organized way, against the recurrence of fascism or extreme-right ideologies in their own societies or on the international stage. It should come as no surprise that this alliance was structured through international organizations. The mobilization for the Second World War was already an international effort, and required the war-time construction of new forms of international cooperation: new chains of command, forms of information sharing, scientific and technical protocols, methods of diplomacy, and cross-border economic coordination. These layered atop the pre-war internationalism of the European empires, which had stitched diverse societies together in global chains of command and networks of production and distribution. Many of these prewar imperial

43. Relatedly, as Polanyi-Levitt argues, the turn to neoliberalism has led to a "crisis of capitalism more profound and intractable than that of the 1930s, because Western democracies are now captive to financial markets." See Kari Polanyi-Levitt, The Power of Ideas: Keynes, Hayek, and Polanyi, 41 InT'L J. PoL. ECON. 5, 6 (2012).

44. See generally Michael Mandelbaum, The Ideas that Conquered the World: Peace, Democracy, AND Free Markets IN the Twenty-First Century (2004) (describing the uneven spread of peace, democracy, and free markets from the wealthy and powerful countries of the world's core, where they originated, to the weaker and poorer countries of its periphery). 
structures and semi-formalized war-time routines were later adapted and formalized in the construction of the post-war liberal world.

International liberalism thus relied on the internationalism of the war effort in seeking to repudiate or transcend the political factors that were argued to have led to the war in the first place. Prominent among its aims was to achieve a different accommodation between the demands of domestic politics and the disciplines of the international marketplace. ${ }^{45}$ The diverse forms of international cooperation that resulted included political, military, diplomatic, economic, cultural, and scientific exchanges through formal treaty structures and informal norms and channels. Some of these, such as NATO or GATT, were specific to the Western alliance. Others, such as the United Nations (UN) and its associated agencies, were more self-consciously universal, spanning the Cold War divide and providing a neutral ground of international recognition for the independent states emerging out of the dying European empires.

While it is tempting to see the history of the post-war period as continuous with the politics of today, recent scholarship in international economic law has analyzed two regimes of "liberalism" instantiated historically. The first was what John Ruggie has called the "embedded liberalism" 46 of the post-war period, visible in the GATT and the first Bretton Woods, while the second is often called "neoliberalism" and began in the 1970s and 1980s with the Tokyo and Uruguay Rounds of the GATT, the conservative economic programs of Reagan and Thatcher, and the triumph of "Washington consensus" policies in the 1990s. ${ }^{47}$ The concept of embedded liberalism was intended to characterize the difference between the post-war liberalism of the late

45. See John Maynard Keynes, National Self-Sufficiency, 22 YALE REV. 955 (1933). For a discussion of "embedded liberalism," see also infra note 46.

46. John Ruggie introduced the term "embedded liberalism" in a famous article that contrasted the economic arrangements of the post-WWII period with those of the pre-WWI world. The attempt to harmonize the construction of a liberal international economic order with domestic political demands for market intervention was reflected most obviously in the international monetary order, which provided Ruggie with many of his chief examples, including the contrast between the Bretton Woods arrangements and the classical gold standard, in which he identified the most severe trade-off between the demands of international integration and domestic policy autonomy. However, the multilateral trading system also reflected this embedded liberal compromise, according to Ruggie, whose focus throughout the original article was on "regimes of trade and money" considered together. See John Gerard Ruggie, International Regimes, Transactions, and Change: Embedded Liberalism in the Postwar Economic Order, 36 INT'L ORG. 379 (1982). Ruggie repeats one version or another of this formulation ("money and trade" or "trade and money") throughout. $I d$ at 381, 383-84, 386, 399.

47. See ANDrew LANG, World Trade Law AFter Neoliberalism: Reimagining the GLOBAL ECONOMIC ORDER 221-73 (2011). 
1940s through 1970s as distinct from the classical liberalism of the nineteenth century. Unlike the earlier liberalism of the nineteenth century, a variety of post-war compromises ensured that international economic liberalization was compatible with domestic legislation that aimed at social protection. This made the new form of international liberalism "embedded," Ruggie claimed, borrowing a term from Karl Polanyi, and thus rendered market opening compatible with purposes that countermanded or transcended market logic. ${ }^{48}$

Any discussion of "international liberalism" and its current crisis must focus on the economic dimension of liberalism, because the crisis of representation and of legitimation both stem in significant respects from changes in global economic policymaking. Economic liberalism must, in turn, be understood in terms of the historical shift from "embedded liberalism" to "neoliberalism." Both embedded liberalism and neoliberalism entail commitments to multilateral economic liberalization, which is what makes each a "liberal" ideology of international economic law. They differ, however, in several respects, including the roles they assign to public and private orderings and to the aim or purpose of the economic liberalization pursued-and hence in the details and the pace of reciprocal opening.

The idea of neoliberalism at the international level may be unfamiliar to some readers. It depends on borrowing a contested term, neoliberalism, which is usually used to characterize the tenor of domestic political economy to analyze trends in geopolitics and global coordination. Neoliberalism generally refers to the return of economic liberalism-that is, laissez-faire and its associated anti-regulatory politics-in the later twentieth century (that is, after the era of embedded liberalism). As Jedediah Purdy and I argued:

"Neoliberalism" refers to the revival of the doctrines of classical economic liberalism, also called laissez-faire, in politics, ideas, and law. These revived doctrines have taken new form in new settings: the 'neo-' means not just that they are back, but that they are also different, a new generation of arguments. What unites the two periods of economic liberalism is their political effect: the assertion and defense of particular market imperatives

48. Owing to the success of Ruggie's article, the juxtaposition of "embedded" and "liberal" may no longer seem as striking, but it was meant as a provocation, given that in Polanyi's account, economic liberalism was a "disembedding” force. Ruggie's claim was that these countertrends had been rendered compatible by the recognition of a plurality of legitimate aims in the post-war period. 
and unequal economic power against political intervention. ${ }^{49}$

The term first came to prominence in Latin America to describe the economic reforms in the 1980s and 1990s-later called the "Washington Consensus"-and the agenda of the Thatcher and Reagan administrations and, after Maastricht, the European Union. ${ }^{50}$ It is often used as a shorthand for "market fundamentalism," though, as Jamie Peck argues, it does not consist of a straightforward anti-regulatory or deregulatory political agenda, because sometimes the introduction of market modes of governance requires not a "roll-back" of regulations but a "roll-out" of new, different ones. ${ }^{51}$ However, whether through deregulation or reregulation, neoliberalism refers, as Purdy and I explained, to the "recurring claims made by policymakers, advocates, and scholars in the ongoing contest between the imperatives of market economies and nonmarket values grounded in the requirements of democratic legitimacy." 52 What is ultimately at stake here is not so much "market fundamentalism," as is often asserted, but expansion of capitalism: not markets in the abstract but "markets deployed to further capital accumulation under present historical conditions." 53

Debates over neoliberalism have mainly concerned the shape of its domestic purview: the range of anti-regulatory, deregulatory, and reregulatory stances, positions, and policies that make up its repertoire. But neoliberalism has an international dimension too. As debates about the "Washington Consensus" in development circles in the $1990 \mathrm{~s}^{54}$ and more recent concerns about internationally imposed austerity in southern Europe ${ }^{55}$ and elsewhere suggest, there is what we might call a "geopolitics of neoliberalism."

What does it mean to diagnose neoliberalism at the international level? What the geopolitics of neoliberalism proposes is that a market-

49. David Singh Grewal \& Jedediah Purdy, Introduction: Law and Neoliberalism, 77 LAW \& CONTEMP. PROBS. 1 (2014).

50. See generally David Harvey, A Brief History of NeOliberalism (2007) (telling the political-economic story of where neoliberalization came from and how it proliferated on the world stage).

51. JAmie Peck, Constructions of Neoliberal REAson 22-23 (2010).

52. Grewal \& Purdy, supra note 49 , at $2-3$.

53. Id. at 3 .

54. For an overview, see DAVID Singh Grewal, Network Power: The Social DyNAMiCs OF GLOBALIZATION 250-51 (2008); see also Charles Gore, The Rise and Fall of the Washington Consensus as a Paradigm for Developing Countries, 28 WoRLD DEV. 789 (2000). For a retrospective, see John Williamson, A Short History of the Washington Consensus, 15 LAW \& Bus. REV. AM. 7 (2009).

55. See Wolfgang Streeck, Markets and Peoples: Democratic Capitalism and European Integration, 73 NEW LEFT REV. 63 (2012). 
led order has pride of place in setting the terms of international relations, and that states defer to and enforce this private (transnational) ordering. The form of legality that this shift to private ordering requires will be discussed in the next section. But it is worth noting here that the crises of representation and of global governance emerge from the expansion of neoliberalism within countries and between them. Thus, the geopolitics of neoliberalism ultimately requires a depoliticization of policy-making within and between countries: that is, a suppression of collective decision-making to the extent that it deviates from what the private market-ordering would entail. ${ }^{56}$

The favorable conditions of the post-war period enabled policymakers to escape the incompatibility of market and political logic, as Thomas Piketty and many others have recently observed. ${ }^{57}$ During these trente glorieuses and within the context of the Cold War, geopolitical and economic initiatives could be tied to the expansion of market relations domestically and internationally. Even so, there were relatively deep problems concerning the sustainability of this post-war political economy. ${ }^{58}$ By the early 1970 s, both the original Bretton Woods currency arrangement and the organization of industrial production within the allied group of Western democracies had begun to unravel. ${ }^{59}$

The result could have been a reconsideration of fundamental questions concerning the organization and distribution of economic production across borders, undertaken as part of a diplomatic-political initiative. Both the most ambitious post-Keynesian planning and, later, the effort at a "New International Economic Order" pushed in this direction. ${ }^{60}$ However, in the end, what resulted was a doubling down on the economic liberalism within international liberalism, with the seeds

56. For a study of depoliticization (and de-democratization), see WoLFGANG STREECK, Buying Time: The Delayed CRisis of Democratic CAPITAlism (Patrick Camiller trans., 2014). For a typology of varieties of "depoliticization," see Yannis Papadopoulos, Multilevel Governance and Depoliticization, in AnTi-Politics, Depoliticization, AND Governance 134, 137 (Paul Fawcett, Matthew Flinders, Colin Hay \& Matthew Wood eds., 2017). For an account of the politics of a privatized economy, see COLIN LEYS, MARKET-DRIVEN POLITICS: NEOLIBERAL DEMOCRACY AND THE PUBLIC INTEREST (2001).

57. See Grewal \& Purdy, supra note 49, at 12-13.

58. As Streeck argues, when the high growth came to an end, a series of policies were attempted to disguise fact. See Wolfgang Streeck, The Crises of Democratic Capitalism, 71 NEW LEFT REV. 5 (2011).

59. On the collapse of the Bretton Woods system and its lessons, see BARRY Eichengreen, Globalizing Capital: A History of the International Monetary SYSTEM 128-133 (2d ed. 2008). For a critical history of the past few decades of capitalist development, see ANDREW Glyn, CAPITAlism Unleashed: FinANCE Globalization AND WELFARE (2006).

60. For a discussion of post-war attempts at global planning, see, for example, Samuel Moyn, Welfare World, 8 HumAN. 175 (2017). 
of neoliberalism visible in the response to the collapse of Bretton Woods, if not earlier. In the United States, this meant the advent of "fast track" as well as new ways of insulating trade policy from increasingly opposed domestic politics. ${ }^{61}$ In Europe, it meant moves (both juridical and otherwise) toward the common market. ${ }^{62}$ In replacing the gold-dollar peg, the construction of a new Bretton Woods arrangement used dollardenominated debt as the anchor in an unequal trade with developmentally oriented East Asia. ${ }^{63}$ This cycle would persist as the way to incorporate China into the global economy even prior to its accession to the WTO in 2001.

There were two major problems with the move toward neoliberalism, one internal and the other external. Internally, a focus on the domestic character of states, including their political constitutions (with great attention paid instead to their economic and financial arrangements), was left out. Very little attention was paid to the social sustainability of what was often elite-led, corrupt ("crony") capitalism so long as it conformed roughly to the desired profile of international capital markets. What was obviously true during the East Asian financial crisis of the 1990s turned out to have analogues and extensions in the United States and elsewhere-as revealed in the aftermath of the 2008 financial crisis. ${ }^{64}$

Externally, with the end of the Cold War, the geopolitics of neoliberalism began in earnest once international economic integration came to be seen as the means of achieving peaceable and equitable international relations globally and not just among a Western-led

61. Adkins \& Grewal, supra note 38, at 1499.

62. See Dieter Grimm, The Democratic Costs of Constitutionalisation: The European Case, 21 Eur. L.J. 460, 467 (2015).

63. See Michael P. Dooley, David Folkerts-Landau \& Peter Garber, An Essay on the Revived Bretton Woods System (Nat'l Bureau of Econ. Research, Working Paper No. 9971, 2003).

64. While the Asian financial crisis of 1997-1998 was often attributed to "crony capitalism," it was obvious even to popular commentators following the U.S. financial crisis that began in late 2007 that the term could be applied in the United States as well. See, e.g., Nicholas Kristof, Crony Capitalism Comes Home, N.Y. TIMEs (Oct. 26, 2011), https://www.nytimes.com/2011/10/27/opinion/kristof-crony-capitalism-comes-homes.html. And for a more careful analysis of what crony capitalism might mean, see Malcolm S. Walter, Crony Capitalism, American Style: What Are We Talking About Here? (Harv. Bus. Sch., Working Paper No. 15-025, 2014). And for the economic sociology of the institutional landscape prior to and following the U.S. financial crisis, see MICHAEL LOUNSBURY \& Paul M. Hirsch, Markets on Trial: The Economic Sociology of the U.S. Financial Crisis: Part A (1st ed. 2010) and Michael Lounsbury \& Paul M. Hirsch, Markets on TRIAL: THE ECONOMIC SOCIOLOGY OF THE U.S. FINANCIAL CRISIS: PART B (1st ed. 2010) (for the economic sociology of the institutional landscape prior to and following the U.S. financial crisis). 
alliance. This deepened economic engagement was viewed as a way to manage, even transcend, historical enmities and present differences in domestic political regimes. As a result, both Russia and China joined the WTO and other international economic arrangements. In the background of this strategy was the sort of "end of history" thinking of the 1990s, which assumed that the relation between the market and state had been settled in existing liberal democracies that represented the form toward which all states would evolve. ${ }^{65}$

The focus on the market as the mechanism of international cooperation (rather than the state and its external diplomacy) has proven especially damaging to the developing world, and in regions of weak or "failed" states. Indeed, the 1990s was a period of continual, low level war in these unstable regions, with a generation of evidence now accumulating that economic reforms without significant politicalinstitutional changes are insufficient to stabilize societies. ${ }^{66}$ The shift in the United States during the 1990s to something like a permanent warfooting-formalized after 2001 in the open-ended "global war on terror"-confirmed and consolidated a trend in which neoliberal integration and military interventions of a "policing" kind proceed together. ${ }^{67}$

However, perhaps the greatest gamble in the geopolitics of neoliberalism was that international rivalry among great powers would be overcome through further economic integration. The effort was to achieve both internal democratic reforms and peaceable external relations in Russia and China through their incorporation into the global capitalist system. Domestically, both Russia under Putin and, more recently, China under its new president without term, Xi Jinping, have moved from rule by one party to rule by one person, thus confounding optimistic predictions that economic liberalization would generate political liberalization. ${ }^{68}$ Likewise, tensions between Russia and China and the United States have not abated and are arguably higher now than they have been since the end of the Cold War. Thus, while almost three decades have passed since the fall of the Berlin Wall,

65. See Susan Marks, The End of History? Reflections on Some International Legal Theses, 8 EUR. J. INT'L L. 449, 451-54 (1997) (discussing Francis Fukuyama's "end of history" thesis).

66. For an overview and critique of this new form of militarized international order, see Samuel Moyn, American Peace in an Age of Endless War, 37 RARITAN 152, 162-65 (2018).

67. For a discussion of the conjunction of neoliberal economics with interventionist foreign policy, see Wendy Brown, American Nightmare: Neoliberalism, Neoconservatism, and De-democratization, 34 POL. THEORY 690 (2006).

68. For recent discussions of Xi Jinping's formal consolidation of power in China, see McGregor et al., supra note 23. 
the most that can be said for the geopolitics of neoliberalism is that its promises remain to be realized. More pessimistically, but perhaps realistically, they have proven a failure: they have failed to bridge historical enmities while undermining the relative strength of liberal democracies vis-à-vis their rivals.

Within the liberal democracies themselves, what has proven most damaging about neoliberalism is its distributive consequences, which were not apparent in the immediate post-war period because neoliberalism was muted by the high and widely shared growth of that time. As neoliberalism took hold, it began to undermine the domestic political bargain in the social-democratic states of the West, which saw bourgeoning inequality. The trend accelerated with the end of the Cold War, when neoliberal reforms were urged on all countries in tandem. Since 2000, and to focus on the United States, we have seen a pincer movement between China's entry into the WTO and the formation of the Euro (which functions, in effect, as an undervalued Deutschemark guaranteed by ongoing instability at the periphery of the Eurozone. ${ }^{69}$ ) This has allowed Germany to take the high end of global manufacturing while China takes the low end. In the United States, approximately a third of manufacturing jobs were lost over this time, compared to a relatively constant baseline during the previous post-war decades. ${ }^{70}$

This loss of manufacturing output must be read against the dramatic evidence on the lack of income growth for the bottom 50 percent of the population since the mid-1970s, meaning that not only one but a second generation of American workers is trapped at the real wages of fifty years ago. ${ }^{71}$ Again, the political consequences of this shift continue to be debated but may have had substantial repercussions in the last presidential election, and in political shifts to come. ${ }^{72}$ Alongside the shock of elite commentary at the alleged working-class revolt in the Rust Belt should come a more sober reflection on the patience of the majority of Americans in trusting their leaders over the last fifty years, during which time flat incomes for working people have tended to be

69. See Wolfgang Streeck, Why the Euro Divides Europe, 95 NEW LEFT REV. 5 (2015).

70. For data, see Scott, supra note 41.

71. For data, see Piketty, Saez \& Zucman, supra note 42.

72. For commentary connecting increasing economic inequality to political changes in the United States, see Thomas Piketty, We Must Rethink Globalization or Trumpism Will Prevail, THE GUARDiAN (Nov. 16, 2016, 6:00 PM), https:/www.theguardian.com/com mentisfree/2016/nov/16/globalization-trump-inequality-thomas-piketty; see also Jedediah Purdy, How Trump Won, JACOBIN (Nov. 11, 2016), https://www.jacobinmag.com/2016/11/ donald-trump-election-polls-whites-working-class; Aziz Rana, Goodbye, Cold War, N+1 (2018), https://nplusonemag.com/issue-30/politics/goodbye-cold-war/. 
disguised through debt-financed consumption fueled by cheap private or public money. ${ }^{73}$

Putting together the above arguments, the apparent crisis of "international liberalism" should be understood as one in which the "embedded liberalism" of the post-war era was hollowed out and betrayed by a post-Cold War "neoliberal" turn in domestic and international politics. Global neoliberalism shares many of the aims of post-war international liberalism but is ultimately incompatible with many of its central premises, particularly its vision of a state-led international legal order, as I argue in the next section below. The negative results of the experiment in global neoliberalism are now increasingly clear but are being confused with the "international liberalism" as such.

Most worrying, what appears now as the crisis of international liberalism may represent in significant respects a reversion to the historic norm, against which the post-war era proved a contingent exception. Two features in particular mark this reversion. First, geopolitical and military rivalry between trading powers generates a highly ambiguous security situation as regards international trade and finance. ${ }^{74}$ Second, the domestic tension between democracy and the free market can no longer be evaded by historically exceptional rates of growth. ${ }^{75}$ Indeed, a depoliticizing tendency now exists both within and between nations, with distributional conflict (or, less politely, class conflict) rendered international: the division of labor within states can be partly transposed into the division of labor (and of capital-labor relations) between or among states. The Eurozone quarrels and the China trade of the United States provide obvious early examples of what proves perhaps the most dangerous product of globalized neoliberalism. For the privileging of market-outcomes usually depends on the possibility of enforcing them using police power, both domestically and through external military means. As Keynes had diagnosed in the 1930s, the depoliticized protection of the market tends to lead to a militarized response to international conflict. ${ }^{76}$

73. See Streeck, supra note 56 (discussing private and public debt in the U.S. democratic-capitalist crisis).

74. See GREWAL, supra note 54, at 235-37.

75. On the history of this return of inequality, its causes and consequences, see David Singh Grewal \& Jedediah Purdy, Inequality Rediscovered, 18 THEORETICAL INQUIRIES IN LAW 61 (2017).

76. See John Maynard Keynes, National Self-Sufficiency, 22 YALE REV. 755 (1933); see also David Singh Grewal, What Keynes Warned About Globalization, 601 SEMINAR 54 (2009) (discussing how the militarized external response presents the global parallel to the police power that enforces neoliberalism at the domestic level). 


\section{NEOLIBERALISM AND THE DIALECTIC OF GLOBALIZATION}

I have argued so far that the "crisis of international liberalism" is best understood as a composite crisis of both domestic political representation and global governance, and that the underlying cause of both has been the turn toward neoliberalism. A neoliberal economic agenda has undermined the post-war settlements both within liberal democracies and between them and non-liberal states, which have been incorporated into the global economic order.

The question remains how law fits into this picture. Is there a form of neoliberal legality? ${ }^{77}$ What is the regime of cross-border governance that best characterizes the neoliberal era in international relations? It has been tempting - as commentators on the left, right, and center have concluded-to understand the neoliberal era as one undergirded by "international" commitments, just as in the earlier liberal era. And it is certainly true that neoliberalism remains a policy choice, made effective on the global stage through treaties and related instruments of international law-making. In that sense, all forms of global governance remain, formally, international (i.e., inter-state). Nevertheless, it may be possible to distinguish what we might call transnational and supranational legality from the international mode of post-war liberalism.

These terms have been used variously across numerous literatures, which I cannot discuss in this essay. As I intend them here, internationalism indicates a form of inter-state cooperation on either cross-border issues (e.g., trade, immigration) or global public goods (e.g., atmosphere, oceans, Antarctica) that does not involve either shared sovereignty or delegation to supranational agencies. An international mode of cooperation presumes the legitimacy of existing borders as establishing distinct regulatory contexts. It thus reflects what Saskia Sassen has described as the state's traditional purview in terms of a triad of sovereignty, exclusive territory, and citizenship. ${ }^{78}$ To the extent that the international management of cross-border flows does impact traditional state functions, it does not do so in a way that challenges the state as the locus of political sovereignty within its own constitutional order. It thus accepts exclusive de jure and some significant measure of de facto control over the activities that occur within its territory, which

77. For two recent collections of papers on the theme of neoliberal legality (at both the domestic and international level) see BEN GOLDER \& DANIEL MCLOUGHLIN, THE POLITICS of Legality in a Neoliberal Age (2017); Honor Brabazon, Neoliberal Legality (2016).

78. Saskia SAssen, Losing Control? Sovereignty in the Age of Globalization 33-34 (1996). 
is predicated on a concept of its individual subjects as citizens. In classical international law theory, the agents (and subjects) of international law are states that exhibit this constellation of sovereignty-territory-citizenship. The post-war regime of "embedded liberalism" may be understood as an effort to achieve many of the benefits of greater economic integration within this international frame.

By transnationalism, I mean, by contrast, a form of inter-state cooperation on cross-border issues that has a deregulatory or privatizing orientation, devolving significant decision-making to individual private actors (either natural individuals or corporations) with the state serving a relatively confined and passive role as the backdrop and guarantor to private, cross-border activity. An example of transnationalism is the shift in the international trade law regime from a concern about tariffs and "at-the-border" issues (e.g., quantitative restrictions based on nationality) to a concern with "behind the border" policy convergence on "next generation" issues such as investment, intellectual property, and regulatory standardization. ${ }^{79}$ Likewise, the international investment regime has a supranational quality in its use of arbitral panels to judge state compliance with treaty obligations. ${ }^{80}$ It is important to note that a great deal of transnationalism may be what Sassen calls "de facto transnationalism," which she has analyzed in the context of migration into the EU. ${ }^{81}$

Finally, by supranationalism I mean to indicate a mode of interstate cooperation in which significant powers, usually regulatory and adjudicatory, are transferred to international agencies with the power to refine or countermand the actions of individual states, without their ongoing consent. The main spur to theoretical reflection on supranational legal forms has been the gradual process of European integration, with "supranational" organs described as emerging from the

79. See generally ANDREW LANG, WORLD TRADE LAW AFTER NEOLIBERALISM: REIMAGINING THE GLOBAL ECONOMIC ORDER (2013) (discussing changes in international economic governance).

80. For a brief overview and assessment, see David Singh Grewal, Investor Protection, National Sovereignty, and the Rule of Law, 2 AM. AFF. 17 (2018), https://amer icanaffairsjournal.org/2018/02/investor-protection-national-sovereignty-rule-law/. For a discussion of the relation of investor state dispute settlement to democratic decisionmaking, see Cory Adkins \& David Singh Grewal, Democracy and Legitimacy in InvestorState Arbitration, 126 YALE L.J. 57 (2016), http://www.yalelawjournal.org /forum/ democracy-and-legitimacy-in-investor-state-arbitration.

81. Saskia Sassen, Beyond Sovereignty: De-Facto Transnationalism in Immigration Policy, 1 Eur. J. Migration \& L. 177 (1999). Note that Sassen's analysis came almost two decades before the migration crisis fueled by the civil war in Syria, and the analysis retains its power. See also JosePH E. STIGLITZ, GLOBALIZATION AND ITS DisconTENTS (2002) (providing an insider's analysis of major institutions and their impact on globalization). 
European treaties in the early 1950s. ${ }^{82}$ But similar supranational construction is apparent in the national delegation of decision-making power to international institutions that evolve through the judgments of what Stone Sweet and Brunell call "trustee courts." 83

What I call the "dialectic of globalization" emerges from the increasing commitment to transnationalism in the global economy. Cross-border private activities are no less prone-and may often be even more susceptible-to generating conflicts and disputes among participants. At the same time, transnationalism alters the traditional constellation of sovereignty-territory-citizenship that defined the state as a legal and political entity by allowing foreign individuals and corporations to make routine (not exceptional) claims on it. The question then becomes: what form of legality is to settle these transnational conflicts?

One relatively straightforward solution to the problems engendered by transnationalism would be to renew forms of national regulation, dependent on existing state sovereignty. It is worth noting that much of the current reaction against neoliberalism today is taking that form. The reassertion of sovereign control over transnational activities over the last decade has perhaps been most obvious in dealing with problems of global finance and migration. Where necessary, this renewal of national regulatory oversight may be made effective through engaging other sovereigns in a process of international legal construction, as occurred prominently in the post-war era. This strategy in effect dissolves (or at least reconfigures) the transnational-with both its problems and perhaps many of its benefits-as the solution to the conflicts it engenders. It reasserts national sovereignty, often in cooperation with other national sovereigns in the construction of international coordinating regimes, and thus reassigns the control of cross-border flows to the traditional structure of state-based legality.

However, what a commitment to transnationalism perhaps more obviously invites is not new international law, which requires the reassertion of state sovereignty as the foundation of international cooperation, but rather new forms of supranational governance.

82. An early observer, Josef Kunz believed that there was no such thing as international (i.e., inter-state) law, but that all non-national law had to be supranational "[f]or 'international law' is, theoretically speaking, a misnomer; if international law is to be law at all, it, by necessity, must be supra-national; if it is to be law at all, it cannot be a law 'between,' but only a law above the states." See Josef Kunz, Supra-National Organs, 46 AM. J. INT'L L. 690, 694 (1952).

83. Alec Stone Sweet \& Thomas L. Brunell, Trustee Courts and the Judicialization of International Regimes, 1 J.L. \& CTS. 61, 62 (2013). See also Mark Thatcher \& Alec Stone Sweet, Theory and Practice of Delegation to Non-Majoritarian Institutions, 25 WEST EUR. POL. 1, 7 (2002). 
Supranational governance promises a form of convergent, harmonized, or otherwise reciprocal treatment across borders, and this mode of legality-not a reassertion of the political at the national level-is what powerful economic actors most require for the maintenance of transnational flows. While the renewal of national regulation necessarily involves the assertion of collective public orderings over private ones in new legal ascriptions, supranationalism enables the possibility of addressing transnational conflicts in a continuing depoliticized mode of legality. Note that this depoliticization may not be merely contingent-as if the supranational were a space of incipient cross-border democratization, as many of its advocates suppose-but instead stems from the coordination required to make national regulatory regimes compatible across borders, as Friedrich Hayek acutely observed in a 1939 essay in which he advocated European unification precisely as a stay against the economic planning that he thought it would preclude. ${ }^{84}$

In a penetrating analysis of international migration and human rights law, Itamar Mann has diagnosed what he calls the "dialectic of transnationalism," a "dynamic that occurs when both policy and its judicial review become transnational." 85 Mann describes three patterns that characterize the dialectic: an initial bifurcation of executive and judicial networks that produce "significant policies beyond the reach of judiciaries;" a consolidation of that bifurcation through transnational judicial decisions; and finally, the replacement of legal rules by "pragmatic problem solving" in transnational law, which has the effect of "eroding the normative basis of human rights." 86 Adopting Mann's reasoning about the effects of cross-border policy activity on the core legal commitments of the state, if not the details of that particular dialectic, we can outline the "dialectic of transnationalism and supranationalism," or, more simply, the "dialectic of globalization." This dialectic describes the way that deregulated cross-border flows (transnationalism) stimulate new forms of cross-border governance (supranationalism) that in turn serve to consolidate further flows.

Sassen was again acute in her implicit diagnosis of this dialectic, and it is worth quoting her at length to the effect that:

[T] he state itself has been transformed by the growth of a global economic system and other transnational

84. Friedrich Hayek, Economic Conditions of Inter-State Federalism, 5 NEW Commonwealth Q. 131 (1939).

85. Itamar Mann, Dialect of Transnationalism: Unauthorized Migration and Human Rights, 1993-2013, 54 HARV. INT'L L.J. 315, 317 (2013).

86. Id. at 315 . 
processes. These have brought on conditions that bear on the state's regulatory role and its autonomy. Two particular aspects of this development are of significance to the role of the state in immigration policy making and implementation [to which we could add all transnational activity]: One is the relocation of various components of state authority to supranational organizations such as the institutions of the European Union, the newly formed World Trade Organization, or the international human rights code. A second is the de-facto privatization of various governance functions as a result of the privatization of public sector activities and of economic deregulation. This privatization assumes particular meanings in the context of the internationalization of trade and investment. 87

Generally, we may observe that the dialectic of globalization emerges from the empowerment of transnational (private) agents, which stimulates a supranational agenda in filling out cross-border governance gaps as necessary. This process is obvious in the transformation of international trade law, where significant private economic flows across borders generate a desire for supranational rather than national governance to address disputes, 88 and in international investment arbitration, in which transnational investment flows are rationalized as requiring supranational adjudicatory structures (whether ad hoc or formalized). ${ }^{89}$ More generally, the strategy of piecemeal European unification has been predicated on the expectation that cross-border economic integration generates problems to which supranational political agency provides the solution. ${ }^{90}$

87. Sassen, supra note 81, at 177. For a similar exploration of how "waning" sovereignty and defensive forms of the state emerge together in a neoliberal dialectic, see generally WENDY BROWn, WALLED States, WANING Sovereignty (2010).

88. As several scholars have noted about the effort of domestic business leaders to push for supranational governance in trade: "Neoliberalism has strong domestic roots and these proved critical in renegotiating the terms of interaction with the global economy and external powers. . . . In all three countries [Australia, Canada, and Mexico] it is clear that a coalition of business interests in support of 'free trade' was critical to the process of the negotiation of the trade agreements." Paul Bowles \& Ray Broomhill, Re-Peripheralisation and Its Alternatives, in InTERnAtional TRADE AND NEOLIBERAL Globalism 179 (Paul Bowles, Ray Broomhill, Teresa Gutiérrez-Haces \& Stephen McBride eds., 2013).

89. See, e.g., Kate Miles, The Origins of InTERnAtional InVESTMENT LAW: EMPIRE, ENVIRONMENT AND THE SAFEgUARDing of CAPITAL (James Crawford series ed., 2013); Gus VAn Harten, Investment Treaty Arbitration AND Public LAW (Vaughan Lowe series ed., 2007); see also Grewal, supra note 80.

90. See Grewal, supra note 20 , at 664 . 
Neoliberal legality thus begins in transnationalism but finds its completion in a depoliticized mode of supranational governance, which in effect extends the model of the "deregulated" national economy to the global level. ${ }^{91}$ To summarize, we may wish to observe the following connections in the study of embedded liberalism and neoliberalism. Post-war embedded liberalism was, in the main, an international mode of governance, excepting the novel and restricted emergence of the supranational in the European Coal and Steel Community. ${ }^{92}$ The neoliberalism that has overtaken it gradually, subsuming its substance while maintaining much of its form, comprises a depoliticized mode of transnational legality, which brings with it pressure toward a supranational mode of governance. While embedded liberalism remains aspirationally inter-state (i.e., international), neoliberalism pushes toward the global oversight of cross-border activity undertaken by private agents. This dialectic works to consolidate a neoliberal orientation to regulation at both the domestic and global levels, generating the crisis of "international liberalism" understood as a composite crisis of domestic representation and global governance.

How does neoliberal legality compare with the traditional statebased legal order as Sassen describes it: a constellation of sovereigntyterritory-citizenship? First, in the place of state sovereignty, we find a new emphasis on governance, which can involve forms of shared and overlapping jurisdiction, extensive delegation to private actors ("publicprivate partnerships"), and a reliance on networked rather than hierarchical modes of social control. ${ }^{93}$ While sovereignty entails a legal order over particular territory, the emphasis in governance is instead on norms. The move from territory to norms entails a potentially openended and flexible process in which the control of activity is indexed not to the location in which it occurs but to the norms which are deemed relevant to its management. The determination of which norms ought to apply to which activities is itself negotiated through the governance process, often with an emphasis on functional attributes and institutional competencies. Finally, in the place of citizens, neoliberal legality emphasizes stakeholders, with some version of the principle of "affected interests" rather than a traditional view of collective self-

91. To repeat a point made above, neoliberal "deregulation" is best understood as reregulatory to other purposes. See Grewal \& Purdy, supra note 49, at 2-3.

92. For a discussion of how the European Coal and Steel Community functioned, and its consequences for broader European integration, see Karen J. Alter \& David Steinberg, The Theory and Reality of the European Coal and Steel Community (Buffett Ctr. for Int'l \& Comparative Stud. Working Paper No. 07-001, 2007).

93. For a discussion of networked modes of social control, see generally DAVID SINGH GREWAL, NETWORK POWER (2008) (arguing that globalization operates through network dynamics best understood as a form of power). 
determination central to the question of who ought to be involved in the process of norm-setting. ${ }^{94}$

The move from the constellation of sovereignty-territory-citizenship to the new constellation of governance-norms-stakeholders is far from complete and may not even be possible to complete, for rather deep reasons I cannot explore here. In different domains of global activity, the transformation may be more advanced than in others, but the purpose of delineating these categories at all is to suggest what the dialectic of globalization pushes toward. The current crisis of international liberalism may thus be decoded as a crisis in the very form of political structure which birthed liberalism, and on which liberalism itself depends.

\section{CONCLUSION: AFTER NEOLIBERALISM?}

In this essay, I have advanced three theses concerning the current crisis of international liberalism. The first is that the crisis is a composite one, comprising interrelated crises of domestic political representation and global governance. The second is that the cause of this crisis has been the turn from the post-war regime of "embedded liberalism" to the "neoliberalism" of recent decades, which has had the effect of undoing the domestic social contracts that underlay post-war political stability even while failing to secure peace and prosperity internationally. The third is that the turn to neoliberalism involves a change in the legal mode of inter-state relations from an international orientation characterizing the first decades of post-war liberalism to a "dialectic of globalization," in which newly empowered transnational activity across states generates pressure for supranational governance above them. Taken together, these three theses suggest that "international liberalism" is threatened by an internal transformation in its own agenda as much as by its external enemies. ${ }^{95}$ It remains unclear, however, though urgent, to determine what direction an international politics after neoliberalism could take.

94. For a discussion of the problem of borders in contemporary political theory and a criticism of the principle of "affected interests" from a standpoint emphasizing democratic solidarity, see Sarah Song, The Boundary Problem in Democratic Theory: Why the Demos Should Be Bounded by the State, 4 INT'L THEORY 39 (2012).

95. For a recent critical engagement with liberal internationalism along these lines, see generally Jahn Beate, Liberal Internationalism: Historical Trajectory and Current Prospects, 94 INT'L AFF. 43 (2018). 